\title{
Dizi ve Filmlerin Değerler Üzerindeki Yansımasına Yönelik Sosyal Bilgiler Öğretmen Adaylarının Görüşleri
}

\section{Social Studies Teachers Candidates' Opinions About the Impact of Series and Films on Values}

Orhan ÜNAL, Sorumlu Yazar, Araştırma Görevlisi.

Ondokuz Mayıs Üniversitesi, Eğitim Fakültesi, Samsun / Türkiye.

orhanunal07@hotmail.com

https://orcid.org/0000-0002-4604-6210

ISSN: 1303-880X

e-ISSN: 2667-7504

http://ded.dem.org.tr

Makale Türü / Article Type:

Araştırma Makalesi / Research Article

Geliş Tarihi / Received Date: 30.03.2021

Kabul Tarihi / Accepted Date: 11.06.2021

Yayın Tarihi / Published Date: 25.06.2021

Tr/En: $\operatorname{Tr}$
Atıf/Citation:Ünal, O. (2021). Dizi ve filmlerin değerler üzerindeki yansımasına yönelik sosyal bilgiler öğretmen adaylarının görüşleri. Değerler Eğitimi Dergisi,19 (41),

s. $277-311$.

https://doi.org/10.34234/ded.906251 
Öz: Sağlıklı bir toplum yapısı oluşturabilmek ve bu ortamı sürdürülebilir kılmak değerlerine sahip çıkan bireylerin varlığı ile mümkündür. Günümüzde değerlerin kazandırılması amacıyla kullanılan çeşitli yöntem ve materyaller bulunmaktadır. Dizi ve filmler aracılığıyla da birçok değer olumlu ya da olumsuz olarak izleyicilerle buluşmaktadır. Bu çalışma dizi ve filmlerinin değerlere yansımasına yönelik öğretmen adaylarının görüşlerini ortaya koymak amacıyla hazırlanmıştır. Araştırma nitel araştırma yöntemine uygun olarak temel nitel araştırma deseninde hazırlanmıştır. Örneklem seçiminde ölçüt örneklem yöntemi kullanılmıştır. Araştırma verileri araştırmacı tarafından hazırlanan görüşme formu aracılığıyla sekiz sosyal bilgiler öğretmen adayı ile yüz yüze görüşme yapılarak toplanmıştır. Verilerin analiz edilmesinde tematik analizden yararlanılmıştır. Araştırma sonuçlarına göre sosyal bilgiler öğretmen adayları değerlerin kazandırılması sürecinde dizi ve filmlerin kullanılabileceğini düşünmektedir. Ancak öğretmen adayları Türk dizi ve filmlerinin genel olarak değerler üzerinde olumsuz yönlerinin olabileceğini de belirtmişlerdir. Araştırmada ulaşılan sonuçlar alanyazında yer alan benzer çalışmalar ile karşılaştırılmıştır. Elde edilen sonuçlar dikkate alındığında değerlerin kazandırılması sürecinde kullanılacak olan dizi ve filmlerin içerik bakımından uygun olmasına dikkat edilmesi gerektiği belirtilmiştir. Ayrıca ailelerin de çocuklarını dizi ve filmlerin içeriği konusunda bilinçlendirmelerinin önemi vurgulanmıştır.

Anahtar Kelimeler: Değer, Dizi, Film, Sosyal bilgiler.

$\&$

Abstract: Creating a healthy society structure and making this sustainable is possible with the presence of individuals who hold on to their values. Nowadays, there are various methods and materials used for teaching values. Through the series and films, many values either positive or negative are conveyed to the audience. This study aims to present the opinions of prospective teachers about values acquisition through series and movies and the effects of Turkish series and films on values. The research utilized the basic qualitative research design in accordance with the qualitative research method. Criterion sampling method was used in sample selection. Research data were collected through face-to-face interviews with eight social studies teacher candidates via the interview form prepared by the researcher. Thematic analysis was used to analyze the data. According to the results of the research, social studies teacher candidates think that TV serials and movies can be used in the process of transmitting values. However, teacher candidates stated that Turkish serials and films generally have 
negative effects on values. The results obtained in the research were compared with similar studies in the literature. When the results are taken into consideration, it could be said that TV serials and films to be used in the process of instilling values should be suitable in terms of content. Another point that should be emphasized is that families need to increase their children awareness about the content of the series and films they are exposed to.

Keywords: Value, Series, Film, Social studies.

(The Extended Abstract is at the end of the article)

\section{Giriş}

Değerler, milli ve küresel gelişime elverişli olan hayat prensiplerini yönlendiren, hayata yön, dayanma gücü, yaşama sevinci, mutluluk, huzur vb. getiren olgulardır (Ulusoy, 2019, s. 65). Aynı zamanda değerler toplumun geneli tarafından doğru ve güzel olarak tanımlanan ve kabul gören davranışlardır. İnsanlar değerlere sahip olarak doğmazlar. Ancak yaşantıları, yaşanmışlıkları, çevreleri ve aldıkları eğitim sayesinde bu değerleri kazanabilirler (Yeşil ve Aydın, 2007, s. 65). Dolayısıyla değerlerin kazandırılabilmesi amacıyla çeşitli yöntemler kullanılmakta, çeşitli çalışmalar yürütülmekte ve çeşitli programlar uygulanmaktadır. Değerlerin öğrencilere ve toplumu oluşturan bireylere kazandırılması amacıyla yürütülen çalışmalar ve gösterilen gayret ise değerler eğitimi olarak tanımlanabilir (Ulusoy, 2019, s.92).

İçinde bulunduğumuz toplumun yaşanılabilir olması değerlerine sahip çıkan ve bunu gelecek nesillere aktarma gayretinde olan bireylerin varlı̆̆ıyla mümkün olacaktır (Kaymakcan ve Meydan, 2020). Özellikle bireyselleşme ve ben merkezci düşünce yapısının getirdiği olumsuzluklara sahne olan günümüzde değerler eğitiminin önemi daha iyi anlaşılmaktadır (Blaylock, 2003; Kaymakcan ve Meydan, 2010; Kaymakcan ve Meydan, 2020). Toplumsal alanda yaşanan gelişmeler ve küreselleşmenin etkisinin oldukça arttığ 1 son yirmi yıllık süreçte değerlerin ve değerler eğitiminin önemi ve bu konuda yapılan çalışmalar artmıştır (Aydın ve Gürler, 2014; Biesta, 2010; Coates, 2005; Gündüz, 2016; Kaymakcan ve Meydan, 2020; Şahin ve Ersoy; 2012; Ulusoy ve Dilmaç 2012; Ünal, 2020a; Ünal, 2020b) Yapılan çalışmaların, toplumda unutulmaya yüz tutmuş değerlerin tekrar yer edinilmesinde, değerlerine sahip çıkan bireylerin yetiştirilmesinde ve toplumsal sorunlara kalıcı çözüm üretilmesinde yararlı olacağı düşünülebilir (Demirkaya ve Çal, 2018). 
Değerler eğitimi ailede başlar ve okulda devam eder. Çocukların karakter özelliklerinin gelişmesi noktasında ailenin rolü ne kadar etkiliyse değerler eğitimi noktasında da aileye büyük görev ve sorumluluk düşmektedir (Demir, 2018, s.1). Çocuklar belirli bir yaşa gelinceye kadar herkesten fazla anne ve babalarını görürler, onları izlerler ve takip ederler. Bu noktada ebeveynlerin davranışları, yaşantıları, hal ve hareketleri çocukları üzerinde büyük etkiye sahiptir. Anne babaların çocuklarına hal ve hareketleri ile olumlu örnek olmaları, çocukların karakter gelişimine ve değerlere saygılı bireyler olarak yetişmelerine katkı sağlayacaktır. Çocukların karakter gelişimi ve iyi insan olarak yetişmesine rol sahibi diğer bir kurum da okullardır. 12 yıllık zorunlu eğitimin olduğu Türkiye'de çocuklar zamanlarının önemli bir kısmını okullarda geçirmektedir. Okullarda uygulanan öğretim programları, öğretmenler ve arkadaş çevresi çocukların karakter gelişimi ve değer kazanımları üzerinde etkileyici güce sahiptir (Ulusoy, 2019, s. 159). Aile ve okul faktörlerinden sonra son olarak çevre faktörü de karakter gelişimi ve değer aktarımında etkili olan bir unsurdur. İnsanların karakterleri ve kişilik özellikleri küçük yaşlarda şekillenmeye başlar. Bundan dolayı ailede başlayan eğitim okul ve çevre faktörleri ile de desteklendiği zaman topluma ve kendisine faydalı iyi insan yetiştirme yolunda büyük bir adım atılmış olur (Doğanay, 2009, s. 233).

Türkiye'de okullarda değerler eğitiminin tarihi çok eskilere dayanmasına rağmen yakın döneme kadar öğretim programlarında değerler eğitimine doğrudan yer verilmemiştir (Kaymakcan ve Meydan, 2020, s 216). Özellikle sosyal bilgiler dersi öğretim programları dikkate alındığında değerlerin doğrudan öğretim programında yer alması 2004 yılında yayınlanan, 2004-2005 öğretim yılında pilot uygulaması yapılan ve 2005-2006 öğretim yılında ülke genelinde uygulanmaya başlanan Sosyal Bilgiler Dersi Öğretim Programı ile mümkün olmuştur. Bu programda değerlerin özellikleri sıralanmış, öğretim yöntemleri ayrıntılı olarak açıklanmış, ders kapsamında kazandırılacak olan değerler belirtilmiş ve son olarak sınıf ve ünitelere göre doğrudan verilecek değerler ifade edilmiştir (Keskin, 2008, s. 309). Benzer şekilde 2018 yılında yayınlanan Sosyal Bilgiler Dersi Öğretim Programında da değerlere doğrudan yer verilmiştir (Millî Eğitim Bakanlığ1 [MEB], 2018, s. 9).

Değerlerin kazandırılması amacıyla çeşitli yöntemler ve materyaller kullanılmaktadır. Özellikle teknolojik gelişmelerin ve medya sektörünün insanlar ve insanların gündelik alışkanlıkları üzerindeki etkisinin bir hayli hissedildiği günümüz dünyasında dizi ve filmler bu süreçte etkili materyaller olarak karş1- 
mıza çıkmaktadır. Aslında filmlerin eğitim amaçlı kullanımı film makinesinin icadından hemen sonra olmuştur. Lumiére kardeşlerin 1895 'te film makinesini bulmalarının üzerinden çok bir süre geçmeden filmler 1907'de eğitim amaçlı materyaller olarak kullanılmaya başlanmıştır (Yakar, 2013, s. 22). Burada filmlerin geçmişten günümüze eğitim amaçlı kullanıldığından daha fazla propaganda aracı olarak kullanıldığını da belirtmek faydalı olacaktır.

Dizi ve filmlerin ilgi çekici olmaları ve birden fazla duyu organına hitap edebilmelerinin yanında kolay ulaşılabilir olmalarının da insanlar tarafından tercih edilmelerinde etkili olduğu söylenebilir. Radyo ve Televizyon Üst Kurulu (RTÜK) tarafından her yıl düzenli olarak yayınlanan veriler dikkate alındığında Türk halk1 2018 y1lında günlük ortalama 3 saat 34 dakika televizyon izlemektedir. Aynı raporda haber programlarından sonra en çok izlenen program türünün Türk dizileri olduğu sonucuna ulaşılmıştır (RTÜK, 2018, s. 14). Yine RTÜK tarafından Ocak 2020'de yayınlanan "Çocukların Medya Kullanım Alışkanlıkları ve Siber Zorbalık Araştırması" adlı çalışma güncel durum hakkında bilgi vermesi açısından oldukça kıymetlidir. Araştırma Türkiye genelinde 26 ilden 3.029 ortaokul öğrencisinin katılımı ile gerçekleştirilmiştir. Araştırma sonuçlarına göre öğrenciler günlük ortalama 1 saat 26 dakika cep telefonu kullanmakta, 1 saat 29 dakika televizyon izlemekte, 2 saat 13 dakika internet kullanmakta ve 1 saat 30 dakika da ders çalışmaktadırlar. Ortaokul öğrencileri tarafından en fazla izlenen program türünün $\% 51,5$ oranıyla dizi filmler, $\% 41$ ile filmler ve $\% 28$ oranıla canlı spor müsabakaları/spor programları olduğu araştırmanın en dikkat çekici bulguları olarak öne çıkmaktadır (RTÜK, 2020). Araştırmaların sonuçları dikkate alındığında dizilerin gerek yetişkinler gerekse çocuklar için günlük yaşamın önemli bir yerini işgal ettiği daha iyi anlaşlacaktır. Türk halkının filmlere olan ilgisi de yıllar geçtikçe artmaktadır. Türkiye'de gösterime giren filmleri sinema salonlarında; 2005 yaklaşık olarak 27 milyon 800 bin kişi, 2010 yılında 41 milyon 500 bin kişi, 2015 yılında 60 milyon 200 bin kişi ve 2018 yılında ise 70 milyon 400 bin kişi izlemiştir. Ayrıca yıllara göre gösterime giren film sayılarında da yıllar ilerledikçe artış olmuştur. 2005 yılında 355, 2010 y1lında 379, 2015 yllında 530 ve 2018 yılında ise 638 film gösterime girmiştir (Box Office Türkiye, 2019). Bu istatistiki veriler Türkiye'de dizi ve filmlere olan ilgiyi ortaya koyması bakımından oldukça değerlidir.

Günlük yaşantımızda önemli bir yer edinen dizi ve filmlerin kısa zamanda geniş kitlelere ulaşma imkânına sahip olması ve verdiği mesajlarla izleyiciler üzerinde etki gücüne sahip olması dizi ve filmlerin farklı açılardan incelen- 
mesini gerektirmektedir. Filmler içinde bulunduğu toplumdan beslendiği gibi aynı zamanda o toplum üzerinde etki gücüne sahiptir (Akınc1 Yüksel, 2015, s. 4). Russell III ve Waters (2013, s. 305), filmlerin eğitim ortamlarda kullanılmasının öğrencilerin karakter gelişimleri üzerinde olumlu katkı sağlayacağını savunmuşlardır. Filmlerin anlamlı bir tamamlayıcı olma gücüne sahip olmasından dolayı eşsiz bir öğretim aracı olduğu aynı araştırmacılar tarafından ifade edilmiştir.

Öğrenciler filmler yardımıyla ahlaki ikilem tartışmaları yapabilir, kendi duygu, düşünce, tutum ve inançlarını karşılaştırabilir ve sağlıklı karar alma becerilerini geliştirebilirler (Öztaş, Anıl ve Kılıç, 2013; Smithikrai, 2016). Dizilerin değerler eğitimi sürecinde kullanılması filmlerden biraz daha farklılık göstermektedir. Çünkü diziler filmlerin aksine uzun soluklu yapımlardır ve belli aralıklarla yayınlanmaktadır. Bundan dolayı bir dizinin tamamının (doğrudan bu amaç için hazırlanmamışsa) değerler eğitimi sürecinde kullanılması mümkün değildir. Bunun yerine dizilerin tamamını sürece dahil etmek yerine içerik bakımından uygun olan kesitlerin seçilerek sürece dahil edilmesi daha uygun olacaktır.

Yapılan çalışmalar dizi ve film kahramanlarının insanlar üzerinde etki bıraktığ 1 , insanların bu kahramanlar ile kendilerini özdeşleştirerek onlar gibi davranmaya çalıştıklarını ortaya koymaktadır. Erjem ve Çağlayandereli (2006, s. 27) 1020 öğrenciden elde ettikleri verilerden öğrencilerin üçte ikisinin izledikleri dizilerin kahramanlarını ya da temel karakterlerini fiziki ve kişilik özellikleri başta olmak üzere modelledikleri sonucuna ulaşmışlardır. Parke vd. (1977), doğal ortamlarında şiddet içerikli filmleri izleyen çocukların, şiddet içerikli olmayan filmleri izleyen çocuklardan daha agresif olduklarını belirtmişlerdir. Dalton vd. (2003), çalışmalarında filmlerde sigara içenleri izlemenin ergenler arasında sigara içmeyi teşvik ettiğine yönelik güçlü kanıtlara ulaştıklarını ifade etmişlerdir. Benzer bir çalışmada Dal Cin vd. (2009), dış faktörler kontrol edildikten sonra bile filmlerin alkol kullanımında önemli bir belirleyici olduğu sonucuna ulaşmışlardır. Benzer durum yetişkinlere yönelik film karakterlerinde geçerli olduğu gibi çizgi film karakterleri için de geçerlidir. Özdemir Adak ve Ramazan (2012), anasınıfı ile 1., 2., ve 3. sınıf düzeyindeki öğrenci velilerinin katılımı ile gerçekleştirdikleri çalışmada, çocukların izledikleri çizgi film kahramanlarından etkilendikleri, kendilerini çizgi film kahramanları ile özdeşleştirdikleri ve çizgi filmlerle bağlantılı taleplerde (çizgi filmlerde görülen yiyecek, giysi ve eşyaların talep edilmesi gibi) bulundukları sonuçlarına ulaşmışlardır. Filmlerin 
karakter üzerindeki etkisin yanında bir kültür aktarım aracı olduğunu vurgulayan çeşitli çalışmalar da mevcuttur. Ağırseven ve Örki (2017), 2000’li yıllarda Türk dizilerinin Ortadoğu, Orta Asya, Balkanlar ve Güney Amerika'nın çeşitli ülkelerine ihraç edilmesinden yola çıkarak bu dizileri, insanları çeşitli noktalarda etkileme başarısına sahip "yumuşak güç" olarak tanımlamışlardır. Çalışmada Türk dizilerinin izleyicileri, özellikle Türkiye'yi ziyaret etme isteği noktasında etkilediği vurgulanmıştır. Kim, Agrusa, Lee ve Chon (2007, s.1351), çalışmalarında Winter Sonata isimli Kore dizisinin Japon turistlerin Kore'yi ziyaret etmeleri üzerindeki etkisini incelemişlerdir. İlgili dokümanların ve Kore'ye gelen Japon turistlerle yapilan anketlerin analiz edilmesi sonucunda Japon turistlerin Kore'yi ziyaret etmelerinde izledikleri televizyon dizisinin etkili olduğu bulgulanmıştır. Filmlerin çocukların algıları üzerindeki etkisine odaklanan bir çalışmada Miller (2015), kekemelikle ilgili olumsuz film kesitleri izleyen ergenlerin, kekemelikle ilgili nötr film kesitleri izleyen ergenlere göre kekeme insanlara karşı daha olumsuz algıya sahip oldukları sonucuna ulaşmıştır.

Alanyazında filmlerin yanında dizilerin de insanlar üzerindeki etkisini ortaya koyan çalışmalar yer almaktadır. Semerci ve Kalçık (2017, s.256) lise öğrencileri ile yaptıkları çalışmada TV dizilerinin öğrencilerin yaşam boyu öğrenmeleri üzerinde etkili olduğu sonucuna ulaşmışlardır. Aynı çalışmada öğrencilerin dizilerde geçen konuşmaları ve cümleleri günlük yaşamda kullandıkları, meslekleri tanıma ve seçmede olumlu olarak etkilendikleri, dizi karakterlerini kendilerine örnek aldıkları, onlar gibi davranmaktan hoşlandıkları bununla birlikte dizilerde gösterilen bazı olay ve kişilerden olumsuz olarak etkilendikleri sonucuna ulaşılmıştır. Xu (2018), Çin'de yayınlanan çevrimiçi Amerikan TV dizilerinin izleyicilerin gerçeklik, kültürel değerler ve kimlik algıları üzerindeki etkisini incelemiştir. Araştırmada, Çin hükümetinin Amerikan TV dizilerinin Çin izleyicilerin kültürel değerleri üzerindeki etkisi konusunda endişe duyduğu vurgulanmış, hükümetin bu dizilerden dolayı geleneksel Çin kültürel değerlerinin kaybolmasından korktuğu dile getirilmiştir. Araştırmada ayrıca Çin'de Amerikan TV dizilerini izleyenler arasında Amerikan değerlerinin geliştiği sonucuna ulaşılmıştır. Dolayısıyla Amerikan dizileri Amerikan değerlerini aktarmak amacıyla kullanılan bir araç olarak da karşımıza çıkmaktadır. Özturhan (2019), çalışmasında İmam Hatip liselerinde okuyan kız öğrencilerin Kore dizilerinden etkilendikleri, bu dizilere ve dizilerin kahramanlarına hayranlık duydukları sonucuna ulaşmıştır. Araştırmacı bu dizilerin değerlerimizle bağdaşmayan unsurlarının Türk milli ve manevi değerleri üzerinde olumsuz bir etkiye sahip olduğu yorumunda bulunmuştur. 
Sosyal bilgiler dersi 4, 5, 6 ve 7. sinıflarda okutulan temel dersler arasinda yer almaktadır. Vatanını ve milletini seven, sorumluluklarının farkında olan, demokratik, laik, millî ve çağdaş değerleri yaşatmaya istekli bireyler yetiştirmek sosyal bilgiler dersinin başlıca amaçları arasında yer alır. Ayrıca sosyal bilgiler dersi kapsamında öğrencilerin millî, manevi değerleri ile evrensel değerleri benimseyebilmeleri de amaçlanmaktadır (MEB, 2018, s.8; Sözer, 1998). Millî Eğitim Bakanlığı (MEB) tarafından yayınlanan Sosyal Bilgiler Dersi Öğretim Programı incelendiğinde diğer temel derslere göre sosyal bilgiler dersinin değerlerin kazandırılmasında en etkili derslerden biri olduğu daha iyi anlaşılacaktır (MEB, 2018, s. 8). Yine sosyal bilgiler dersinin tarih, vatandaşlık bilgisi gibi alanlara hitap eden yapısı ders sürecinde dizi ve filmlerin kullanımına olanak sağlamaktadır. Bu anlamda yapılan çok sayıda çalışmada, dizi ve filmlerin eğitim öğretim sürecinde kullanılabilecek materyallerden olduğu ifade edilmiştir (Gezici ve Demir, 2016; Kaya ve Çengelci, 2011; Sturma (1997). Sosyal bilgiler dersinin değerler eğitimi açısından sahip olduğu önem ve ders içeriğinin dizi ve filmlerin kullanımına uygun yapısı göz önünde bulundurulduğunda dizi ve filmlerin değerler üzerindeki etkisine yönelik görüşler kıymet kazanmaktadır. Buradan hareketle değerler eğitiminde dizi ve film kullanımına yönelik sosyal bilgiler öğretmen adaylarının görüşlerinin incelenmesi faydalı olacaktır. Zira öğretmenlerin sahip oldukları bilgi, birikim, inanç, duygu ve düşünceler onların eğitim-öğretim faaliyetleri üzerinde etki sahibidir (Banks ve Banks, 2007). Dolayısıyla öğretmen adaylarının, değerlerin kazandırılmasında dizi ve filmlerin etkisine ilişkin görüşlerinin, bu materyalleri değerler eğitimi sürecinde kullanma durumları ile doğrudan alakalı olduğu söylenebilir.

$\mathrm{Bu}$ bilgilerden hareketle çalışmanın temel amacı; sosyal bilgiler öğretmen adaylarına göre dizi ve filmlerin değerlere olan yansımasını ortaya koymak olarak belirlenmiştir. Bu kapsamda şu sorulara yanıt aranmıştır:

1. Sosyal bilgiler öğretmen adaylarının dizi ve filmlerin değerler eğitiminde kullanılmasına ilişkin görüşleri nelerdir?

2. Sosyal Bilgiler öğretmen adaylarına göre dizi ve filmleri değer eğitiminde kullanırken nelere dikkat etmek gerekir?

3. Sosyal bilgiler öğretmen adaylarına göre Türk dizi ve filmlerinin değerler üzerindeki yansıması nasıldır? 


\section{Yöntem}

\section{Araştırma Modeli}

Araştırma nitel araştırma yöntemine uygun olarak hazırlanmış ve temel nitel araştırma deseni kullanılmıştır. Nitel araştırmalar; temel olarak verilerin sayılarla ifade edildiği ve bu şekilde sunulduğu nicel araştırmaların aksine bir durumu derinlemesine incelemeye olanak sağlayan ve soruların ayrıntılı olarak incelenmesine ve yorumlanmasına izin veren araştırmalar olarak değerlendirilebilir (Strauss ve Corbin, 1997). Temel nitel araştırma ise katılımcıların bir konu hakkındaki görüş ve düşüncelerini nitel verilerle ortaya koymak amacıyla yapılan çalışmalar olarak ifade edilebilir. Belki de eğitim alanında en çok kullanılan nitel araştırma deseni olan temel nitel araştırmalarda temel amaç incelenen konu hakkındaki anlamları ortaya çıkarmak ve yorumlamaktır (Merriam ve Tisdell, 2015, s. 25). Araştırma kapsamında sosyal bilgiler öğretmen adaylarının ilgili konuya yönelik görüşleri ortaya koyulmaya çalışılmıştır. Dolayısıyla araştırmada temel nitel araştırma deseninin kullanılması uygun görülmüştür.

\section{Çalışma Grubu}

Araştırmanın çalışma grubunu Türkiye'nin kuzeyinde yer alan bir devlet üniversitesinin sosyal bilgiler öğretmenliği programında öğrenim gören sekiz sosyal bilgiler öğretmen adayı oluşturmaktadır. Çalışma grubunun seçilmesinde amaçlı örneklem yöntemlerinden ölçüt örneklem yöntemi kullanılmıştır. Bu doğrultuda katılımcıların seçilmesinde, son üç ayda en az bir sinema filmi seyretmiş olması ve düzenli olarak en az bir dizi takip ediyor olması ölçütleri ile katılımcıların lisans eğitiminin üçüncü ve dördüncü sınıfında olması ölçütü dikkate alınmıştır. Sınıf düzeyi ölçütünün belirlenmesinde, katılımcıların ilgili programda iki seneden fazla süredir eğitim almalarından dolayı konu hakkında daha fazla birikime sahip olacakları düşüncesi etkili olmuştur. Araştırmada katılımcıların bilgilerinin gizliliğini koruyabilmek amacıyla gerçek isimleri yerine kod kullanımı (K1, K2 ve K3 gibi) tercih edilmiştir. Çalışma grubuna ilişkin veriler Tablo 1.'de sunulmuştur. 
Tablo 1: Çalışma Grubunda Yer Alan Katılımcılara İlişkin Veriler

\begin{tabular}{lllll}
\hline $\begin{array}{l}\text { Öğretmen } \\
\text { Adayı Kodu }\end{array}$ & Cinsiyet & Sınıf & $\begin{array}{l}\text { Izlenen Film Sayısı } \\
\text { (Son 3 Ay) }\end{array}$ & $\begin{array}{l}\text { Düzenli Takip Edilen Dizi } \\
\text { Sayısı }\end{array}$ \\
\hline K1 & Erkek & 3. sinıf & 1 & 2 \\
\hline K2 & Erkek & 3. sinıf & 4 & 4 \\
\hline K3 & Erkek & 3. sinıf & 5 & 3 \\
\hline K4 & Erkek & 4. sinıf & 4 & 8 \\
\hline K5 & Erkek & 4. sinıf & 4 & 3 \\
\hline K6 & Kadın & 3. sinıf & 3 & 3 \\
\hline K7 & Kadın & 3. sinıf & 3 & 4 \\
\hline K8 & Kadın & 4. sinıf & 6 & 4 \\
\hline
\end{tabular}

Araştırmaya katılan öğretmen adaylarının beşi erkek, üçü kadındır. Katılımcıların beşi üçüncü sınıf öğrencilerinden, üçü ise dördüncü sınıf öğrencilerinden oluşmaktadır. Ayrıca katılımcıların tümü düzenli olarak en az iki dizi takip etmekteyken, son üç ayda da en az bir film seyretmişlerdir.

\section{Veri Toplama Araçları}

Araştırma verileri araştırmacı tarafından hazırlanan görüşme formları arac1lığıyla toplanmıştır. Görüşme formu alanyazında yapılan benzer çalışmaların incelenmesi sonucunda oluşturulmuştur. Hazırlanan görüşme formu öncelikle sosyal bilgiler eğitimi ve nitel araştırma yöntemleri konusunda uzman olan bir öğretim üyesi tarafindan incelenmiştir. Uzman görüşü doğrultusunda form, biçim bakımından gizlilik beyanı ve kişisel bilgilerin korunması noktalarında, içerik bakımından ise alt ve olası sonda soruların belirlenmesi noktasında yeniden düzenlenmiştir. İkinci aşamada görüşme formunun amaca hizmet edip etmediğini kontrol etmek amacıyla çalışma grubunda yer almayan bir öğretmen adayı ile görüşme yapılmıştır. Bu görüşme göz önünde bulundurularak görüşme formundan, amaca hizmet etmediği görülen iki alt soru çıkarılmış ve görüşme formu son halini almıştır.

Formun ilk kısmında katılımcıların konu hakkında bilgilendirilmesi amacıyla hazırlanmış giriş metni ve katılımcılara ilişkin bilgiler bölümü yer almaktadır. Görüşmeye başlamadan önce katılımcılar araştırma kapsamında kişisel bilgilerine ilişkin bilgilerinin gizli tutulacağı, çalışmanın güvenilir sonuçlar verebilmesinin kendi görüşlerini yansıtan cevaplara bağlı olduğu, katılımın gönüllülük esasına dayalı olduğu ve görüşmenin ses kayıt cihazı ile kayıt altına alınacağı konularında bilgilendirilmişlerdir.

Görüşme formunda çalışma grubunda yer alan öğretmen adaylarının yanıtlaması için iki tane açık uçlu görüşme sorusuna yer verilmiştir. Bu sorulardan 
birincisi öğretmen adaylarının dizi ve filmler aracılığıyla değerlerin kazandırılmasına yönelik görüşlerini incelemek, ikinci soru ise günümüz Türk dizi ve filmlerinin değerler üzerindeki yansımasına yönelik öğretmen adaylarının görüşlerini incelemek amacıyla hazırlanmıştır. Birinci soruya yönelik; "Film ve diziler aracıliğlyla değerler kazandirllırken nelere dikkat etmek gerekir?” ve "Değer kazandırmak amacıyla kullanılacak film ve diziler seçilirken nelere dikkat edilmelidir?" gibi alt sorular hazırlanırken, ikinci soruya yönelik de "İzlediğiniz Türk dizi ve filmlerin değerlerimizle bağdaştığını düşünüyor musunuz? Niçin?" sorusu gibi alt görüşme soruları hazırlanmıştır. Ayrıca her iki soruya yönelik derinlemesine ve hedefe yönelik bilgi edinmek amacıyla sonda sorular hazırlanmış, görüşme sırasında ihtiyaç duyulması halinde sorular çeşitlendirilmiş ve katılımcının yanıtlarını açıklaması sağlanmaya çalışılmıştır.

\section{Verilerin Toplanması ve Analizi}

Araştırma verileri 2019-2020 eğitim öğretim y1lında nitel araştırmalarda sıkça kullanılan görüşme yöntemiyle toplanmıştır. Görüşme, önceden tasarlanmış, belli bir amaç için yapılan ve soru sorma cevap verme esasına dayanan karş1lıklı ve etkileşimli bir iletişim sürecidir (Stewart ve Cash, 1985; akt. Yıldırım ve Şimşek, 2018, s. 129). Görüşme ofis ortamında katılımcılarla yüz yüze yapılmış, görüşmeler 10-25 dakika arasında sürmüş ve görüşmenin kayıt altına alınabilmesi amacıyla ses kayıt cihazı kullanılmıştır. Ses kayıtları bilgisayar ortamına aktarılmış, Microsoft Word programı yardımıyla yazıya dökülerek transkriptler oluşturulmuştur.

Verilerin analiz edilmesinde tematik analiz kullanılmıştır. Tematik analiz, verilerdeki örüntüleri (temaları) saptama, analiz etme ve raporlama için özellikle nitel araştırmalarda tercih edilen bir yöntemdir (Braun ve Clarke, 2019). Tematik analizde veri setindeki ortak yönler, bağlantılar ve ayrışmalar temelinde veri analizi süreci gerçekleştirilir. Tematik analiz kavramında yer alan tematik kelimesi ise veriler içinde toplu temaların aranması anlamı taşımaktadır (Gibson ve Brown, 2009). Tematik analiz sayesinde incelenen konu bütüncül bir bakış açısıyla ve derinlemesine ele alınır. Böylece, araştırma konularının eğilimini ve öncelikli alanlarını ortaya koymak mümkün olabilir (Çalık ve Sözbilir, 2014). Verilerin analiz edilmesi sürecinde soru bazlı analiz yapılmıştır. Yani öncelikle bütün katılımcıların birinci soru ve bu soruyla bağlantılı alt sorulara verdikleri yanıtlar analiz edilmiş daha sonra da bütün katılımcıların ikinci soruya verdikleri yanıtlar benzer şekilde analiz edilmişsir. Araştırma kapsamında analiz 
edilen veriler benzerliklerine göre kodlar ve temalar altında sunulmuş, kod ve temaları destekleyici bazı katılımcı görüşleri de doğrudan alıntılar yapılarak aktarılmıştır.

\section{Geçerlik ve Güvenirlik}

Geçerlik ve güvenirlik kavramları daha çok nicel araştırmalarda karşımıza çıksa da nitel araştırmalarda da araştırmanın geçerli ve güvenilir sonuçlar sunması açısından önemli bir yere sahiptir (Yıldırım ve Şimşek, 2018, s. 269). Araştırmada geçerliliği sağlayabilmek amacıyla araştırma süreci detaylı olarak betimlenmiştir. Araştırma yöntemi, deseni, katılımcılara ve niçin bu katılımcıların seçildiğine ilişkin bilgiler, verilerin toplanması ve analizi süreçleri ilgili başlıklar altında sunulmuş, veriler gerektiği yerlerde doğrudan alıntılar yapılarak aktarılmış ve yorumlanmıştır. Yine alanda uzman bir araştırmacının görüşlerine de bu bağlamda başvurularak araştırmanın geçerliliği artırılmaya çalışılmıştır. Geçerliliğin sağlanabilmesi amacıyla araştırma soruları ile sonuçları karşılaştırmış ve sonuçların sorularla uyuşmasına gayret gösterilmiş, içerik analizinde temalar ve temaları oluşturan alt temaların kendi aralarındaki ilişkisi ile her bir temanın diğerleriyle ilişkisi kontrol edilerek bütünlüğün sağlanmasına dikkat edilmiştir (Yıldırım ve Şimşek, 2018, s. 269). Güvenirliğin sağlanması amacıyla temalara ilişkin bazı katılımcı görüşleri doğrudan verilmiştir. Araştırma sonuçları araştırmaya katılan bazı öğretmen adayları ile paylaşılmış bu sayede katılımcı teyidi sağlanmaya çalışılııştır. Son olarak elde edilen verilerin geçerlik ve güvenirliğin sağlanabilmesi için veriler, analizler ve yorumların başka araştırmacıya sunulması yöntemine başvurulmuş (Paker, 2017, s. 127) ve sosyal bilgiler eğitimi alanında uzman iki öğretim elemanının görüşleri alınmıştır.

\section{Araştırma Etiği}

Araştırmaya katılan öğretmen adayları araştırma öncesinde konu hakkında bilgilendirilmiş ve katılım gönüllülük esasına uygun olarak sağlanmıştır. Yapılan görüşmelerin ses kayıt cihazı ile kaydedileceği katılımcılara bildirilmiş ve her bir katılımcının onayı alınmıştır. Araştırmada katılımcıların kimliklerini belli edecek herhangi bir kişisel bilgi verilmemiş ve gizliliğin sağlanabilmesi amacıyla katılımcıların gerçek isimleri yerine kodlar (K1, K2 ... şeklinde) kullanılmiştır. 


\section{Bulgular}

$\mathrm{Bu}$ bölümde öncelikle sosyal bilgiler öğretmen adaylarının değerlerin kazand1rılması sürecinde dizi ve filmlerin kullanılmasına yönelik görüşlerine yer verilmiştir. Devamında ise bu görüşler doğrultusunda ortaya çıkan üç ana temaya ve temalara ilişkin bilgilere yer verilmiştir. Bu temalar şu şekildedir:

1. Değerlerin kazandırılması sürecinde dizi ve filmleri etkili kılan özellikleri

2. Dizi ve filmler aracılığıyla değerlerin kazandırılması sürecinde dikkat edilmesi gereken noktalar

3. Türk dizi ve filmlerinin değerler üzerindeki yansımasına yönelik sosyal bilgiler öğretmen adaylarının görüşleri

Araştırmaya katılan öğretmen adaylarının tamamı dizi ve filmler aracılığıyla değerlerin kazandırılabileceğini ifade etmişlerdir. Katılımcılardan K1, "Kazandirılabilir. Günümüzde dizi ve film izlemiyorum diyenler çok nadir. Hatta kimse izlemiyorum diyemez. O yüzden izlediğimiz filmlerden de az çok etkileniyoruz" diyerek dizi ve filmlerin yaygınlığına bundan dolayı da etki gücüne sahip vurgu yapmıştır. K4 ise "Kesinlikle kazandirılabilir. Mesela bu dönemlerde fark ettiyseniz askeri dizler çok önemli. Vatan sevgisi, vatan için her şey feda olsun kavramı, savaş dizisi olsun, tarihi dizler ve askeri dizilerimiz milli değerlerimizi vurguluyor. Çok etkili oluyor." ifadesiyle özellikle askeri dizilerin vatan sevgisi gibi değerleri kazandırmada faydalı olabileceği görüşünü dile getirmiştir. K5, "Tabii kazandırllabilir. Diziler ve filmler insana bir şeyler katabiliyor" diyerek; $\mathrm{K} 7$ ise "Kazandirllabilir bence. Çünkü bir dersi görsel olarak görmek daha etkili ve akılda kalıcı olur." diyerek ve aynı zamanda dizi ve filmlerin görselliğine vurgu yaparak dizi ve filmler aracıllğı ile değerlerin kazandırılabileceğini belirtmişlerdir. Görüldüğü gibi katılımcılar tarafından dizi ve filmler yardımıyla değerlerin kazandırılabileceği ifade edilmiştir. Yukarıda da belirtildiği üzere alanyazında bu ifadeyi destekleyici çalışmalar mevcuttur (Karakuş, 2015; Kaya ve Çengelci, 2011).

Araştırma, öğretmen adaylarının dizi ve filmler aracılığı ile değerlerin kazandırılabileceğini belirtmesinden hareketle; dizi ve filmleri bu süreçte etkili kılan özellikler (Niçin kullanılmalı?), dizi ve filmler aracıllğııla değerlerin kazand1rılması sürecinde dikkat edilmesi gereken noktalar (Nelere dikkat edilmeli?) ve Türk dizi ve filmlerinin değerler üzerindeki yansıması temaları altında toplanmiştır. 


\section{Değerlerin Kazandırılması Sürecinde Dizi ve Filmleri Etkili Kılan Özellikleri}

Yukarıda aktarıldığı üzere katılımcılar dizi ve filmlerin değerler eğitimi sürecine katkı sağlayacağını düşünmektedir. Katılımcılar tarafından ifade edilen bu ortak düşünce devamında dizi ve filmlerin değerler eğitimi sürecindeki etkinliğinin nedenlerinin de ortaya çıkarılmasını gerektirmiş ve dolayısıyla katılımcıların bu konudaki görüşlerine başvurulmuştur. Araştırmaya katılan öğretmen adaylarının görüşleri doğrultusunda değerlerin kazandırılması sürecinde dizi ve filmleri etkili kıllan özellikler yedi alt tema altında toplanmıştır. Alt temalar ile katılımcıların temalara göre dağılımı Tablo 2'de sunulmuştur.

Tablo 2. Değerlerin Kazandırılması Sürecinde Dizi ve Filmleri Etkili Kılan Özelliklerine Yönelik Öğretmen Adaylarının Görüşleri

\begin{tabular}{|c|c|c|c|c|c|c|c|c|c|}
\hline Alt Tema & K1 & K2 & K3 & K4 & K5 & K6 & K7 & K8 & $f$ \\
\hline Görselliğe sahip olması & $\checkmark$ & & $\checkmark$ & & $\checkmark$ & $\checkmark$ & $\checkmark$ & & 5 \\
\hline İlgi çekici olması & $\checkmark$ & & & & $\checkmark$ & $\checkmark$ & $\checkmark$ & & 4 \\
\hline $\begin{array}{l}\text { Birden çok duyu organına hitap } \\
\text { etmesi }\end{array}$ & & $\checkmark$ & & $\checkmark$ & & & & $\checkmark$ & 3 \\
\hline $\begin{array}{l}\text { İnsanları etkileme gücüne sahip } \\
\text { olması }\end{array}$ & $\checkmark$ & & & $\checkmark$ & & $\checkmark$ & & & 3 \\
\hline Yaygın olmas1 & $\checkmark$ & & & $\checkmark$ & & & & $\checkmark$ & 3 \\
\hline İnsanların tembel olması & $\checkmark$ & & & & $\checkmark$ & & & & 2 \\
\hline Olayları somutlaştırması & & & & & & & & $\checkmark$ & 1 \\
\hline
\end{tabular}

Tablo 2'ye göre dizi ve filmlerin görselliğe sahip olması, ilgi çekici olması, birden çok duyu organına hitap etmesi, etki gücüne sahip olması, yaygın olması ve olayları somutlaştırması onları bu süreçte etkili kılan özellikler olarak gösterilmiştir. Öğretmen adaylarına göre dizi ve filmlerin "görselliğe sahip olması" onların değerlerin kazandırılması sürecinde en etkili özelliği olarak öne çıkmaktadır. Bu doğrultuda görüş bildiren öğretmen adaylarının birçoğu (K1, K3 K6, K7) dizi ve filmlerin görselliğe sahip olmasının aktarılanların "akılda kalıcı olmasına" katkı sağladığını da belirtmişlerdir. Bu konudaki katılımcı görüşleri aşağıda verilmiştir:

Zaten kitap okuma gibi bir durum pek yaygın değil. Ve gördüklerimiz daha çok akılda kalıcı olduğu için olabilir (K6).

Hem de görsel olarak gördüğ̈̈ şeyleri daha iyi akılda tutabiliyor (K3).

Görsel olması akılda kalmasını artırır. Bir de öğrenciler daha dikkatli dinlemek isteyebilir. Kitap okurken bir anda farklı bir yere dikkati kayabilir ama orada odağı doğrudan film ya da dizi olduğu için dikkati dă̆llmaz ve akılda daha iyi kalır (K7). 
Dizi ve filmlerin görselliğe sahip olması noktasında görüş bildiren son kat1lımc1 K5 ise "Göze hitap ettiği için estetik olarak daha çekici geliyor" diyerek görselliğin estetik anlamda çekiciliğe katkı sunduğunu belirtmiştir.

Öğretmen adaylarına göre dizi ve filmlerin "ilgi çekici olmaları" da onları değerlerin kazandırılması sürecinde etkili kılmaktadır. Bu konudaki katılımcı görüşleri aşağıda verilmiştir:

Ama diziler görsel olarak hikâye olarak anlatıldığı zaman daha çok ilgimizi çekiyor. Gördüğ̈̈müz şeyi aklımızda daha çok tutabiliyoruz hem de takip etme sürükleyiciliği daha fazla artıyor. İlgi çekici olması burada etkili (K1).

Film bize daha basit daha cazibeli geliyor. Bu yönden bir çekiciliği var (K5).

(Ö̈̆rencinin) Kitap okurken bir anda farklı bir yere dikkati kayabilir ama orada odağı doğrudan film ya da dizi olduğu için dikkati dă̆glmaz (K7).

Öğretmen adaylarının bir kısmı, "dizi ve filmlerin birden çok duyu organına hitap etmesi" özelliğinden dolayı bunların değer aktarımı sürecinde etkili olabileceğini düşünmektedir. Adaylar, dizi ve filmlerin birden çok duyu organına hitap ettiğini bundan dolayı da aktarılanların daha çok "akılda kalacağını" da vurgulamışlardır. Bu alt temaya yönelik bazı görüşler şu şekildedir:

Öğrenci kitlesi görerek ve duyarak daha iyi anlar. Yani film ve diziler birçok duyuya hitap eder. O yüzden daha etkileyici olur (K2).

Dizi ve filmler değerlerin kazandırllması sürecinde etkili olur. Çünkü tüm duyu organlarına hitap ediyor, görsel, işitsel (K8).

Görüldüğü gibi öğretmen adayları tarafından özellikle dizi ve filmlerin farklı duyu organlarına hitap ettiğine vurgu yapılmıştır. Bilindiği gibi öğrenme sürecinde farklı duyu organlarının sürece dahil edilmesi öğrenme üzerinde olumlu etkiye sahiptir (Öztürk, 1999; Keleş ve Çepni, 2006). Bu anlamda katılımcıların görüşleri önemlidir.

Öğretmen adaylarının bazılarına göre "Dizi ve filmlerin insanlar üzerinde etki gücüne sahip olmaları" da onları değerlerin kazandırılmasında etkili hale getirmektedir. K1 ve K6'nın bu konudaki görüşleri şöyledir:

İzlediğimiz filmlerden de az çok etkileniyoruz. Mesela hayatımızda izlediğimiz filmlerden dizilerden kesitler oluyor. Takip ettiğim dizilerden örnek verecek olursam, izlediğim bir tarihi dizide Payitaht Abdülhamit'te mesela milli duygular ve gelenek görenekler daha ön plana çıkabiliyor. Bunun için film ve diziler kullanilabilir (K1) 
Insanlar sürekli ekrandan ne görürse oradakileri tekrar etmeye çalışıyor. Ve bu çocuklarda da bayă̆ı etkili aslında (K6).

"Dizi ve filmlerin yaygın olması" gerekçesinden dolayı da bazı öğretmen adayları değerlerin kazandırılması sürecinde dizi ve filmlerin kullanılabileceğini düşünmektedirler. Bu konudaki katılımcı görüşleri aşağıda verilmiştir:

Gerek gençler olsun gerek yaşlılar olsun artık yaşamımızın bir parçası haline geldi dizi ve filmler. Yani dizi ve film izlemiyorum diyenler çok nadir. Hatta kimse izlemiyorum diyemez (K1).

Çünkü özellikle günümüz ögrencileri 7/24 televizyon ve bilgisayar başında bir şeyler izledikleri için bir davranışın kazandırılmasında aşırı etkili olabileceğini düşünüyorum (K8).

Bu başlık altında bazı öğretmen adayları insanların tembel olmasından dolayı dizi ve filmleri takip ettiğini ve dizi ve film izlemenin daha zahmetsiz bir iş olmasından dolayı tercih edildiğini de belirmişlerdir. Her ne kadar bu bulgu doğrudan dizi ve filmleri bu süreçte etkili kılan bir özellik olarak görülmese de dizi ve filmlerin değerler açısından tembel olarak nitelendirilen kişilere de ulaşma imkanına sahip olması ve bu kişileri etkileme potansiyelinin olması oldukça önemlidir.

Çünkü günümüzde tembelleşen ve daha çok televizyon başında kalan bir insan var. Zamanının büyük bir kısmını film ve diziler vb. şeylere ayırıyor (K1).

Bizim Türk milleti biraz daha üşengeç bir millet olduğu için kitap okumayla çok ilgilenmiyorlar. Film bize daha basit daha cazibeli geliyor. Bu yönden bir çekiciliği var (K5).

Son olarak bir katılımcı da dizi ve filmlerin değerleri soyutluktan kurtarıp somut olarak sunmasından dolayı bu süreçte kullanılabileceğini belirtmiştir.

Bunun dişında örnek olarak bir ortam bir olay görüyor. Yani soyut olarak kalmıyor değerler. O değerlerin uygulanışını görebiliyorlar diziler ve filmler sayesinde (K8).

\section{Dizi ve Filmler Aracılığıyla Değerlerin Kazandırılması Sürecinde Dikkat Edilmesi Gereken Noktalar}

Her dizi ve filmin eğitim öğretim sürecinde kullanılamayacağ Özellikle değerler eğitimi gibi önemli bir alanda dizi ve filmlerin seçiminde daha dikkatli olunması gerekmektedir. Öğretmen adaylarının dizi ve filmlerin 
seçiminde nelere dikkat edilmesi gerektiğine ilişkin görüşlerine yer vermek bu noktada önemlidir. Araştırmaya katılan öğretmen adaylarının görüşleri doğrultusunda dizi ve filmler aracılığıyla değerlerin kazandırılması sürecinde dikkat edilmesi gereken noktalar; içeriğe yönelik görüşler ve sürece yönelik görüşler olmak üzere iki alt tema altında toplanmıştır. Alt temalar, kategoriler ve katılımc1ların bunlara göre dağılımı Tablo 3 ’te sunulmuştur.

Tablo 3: Dizi ve Filmler Aracılığıyla Değerlerin Kazandırılması Sürecinde Dikkat Edilmesi Gereken Noktalara Yönelik Öğretmen Adaylarının Görüşleri

\begin{tabular}{|c|c|c|c|c|c|c|c|c|c|c|}
\hline Alt Tema & Kategori & K1 & K2 & K3 & K4 & K5 & K6 & K7 & K8 & $f$ \\
\hline \multirow{5}{*}{$\begin{array}{l}\text { İçeriğe } \\
\text { Yönelik } \\
\text { Görüşler }\end{array}$} & İçerik uygun olmalı & $\checkmark$ & $\checkmark$ & & $\checkmark$ & $\checkmark$ & & & $\checkmark$ & 5 \\
\hline & $\begin{array}{l}\text { Değerler doğru şekilde aktarıl- } \\
\text { malı }\end{array}$ & $\checkmark$ & $\checkmark$ & $\checkmark$ & & & & $\checkmark$ & & 4 \\
\hline & Gerçek hayatla bağlantılı olmalı & & & $\checkmark$ & & & & & $\checkmark$ & 2 \\
\hline & Öğretici olmalı & & & $\checkmark$ & & & & & & 1 \\
\hline & İlgi çekici olmalı & & & & & & & & 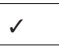 & 1 \\
\hline \multirow{2}{*}{$\begin{array}{l}\text { Sürece } \\
\text { Yönelik } \\
\text { Görüşler }\end{array}$} & Dolaylı olarak anlatılmalı & & & & & & $s$ & & $s$ & 2 \\
\hline & $\begin{array}{l}\text { Assamalılık ilkesi dikkate } \\
\text { alınmalı }\end{array}$ & & & & & & & $\checkmark$ & & 1 \\
\hline
\end{tabular}

Tablo 3'e göre değerlerin kazandırılması sürecinde dizi ve filmler kullan1lırken; içeriğinin uygun olmasına, değerleri doğru şekilde aktarıyor olmasına, gerçek hayattan kopuk olmamasına, öğretici ve ilgi çeki olmasına dikkat etmek gerekmektedir. Öğretmen adaylarına göre dizi ve filmler aracıllı̆ıyla değerlerin kazandırılması sürecinde kullanılacak dizi ve filmlerin "içerik bakımından uygun olması" bu süreç için en önemli noktadır. Bu konudaki katılımcı görüşleri aşağıda verilmiştir:

Benim için önemli olan nokta; (dizi ve filmlerin) bir ailenin izleyebileceği şekilde olması, toplum ahlakina ters düşmemesi, şiddet ve olumsuz yollardan uzak tutmasıdir (K1).

Genel izleyici kitlesine uygun olması lazım. Ailecek izlenebilmesi, çocuklara uygun olması lazım. Onun dışında anarşi gibi topluma çok aykırı içeriğe sahip olmaması lazım (K2).

Mesela Çukur diye izlediğim bir dizi var. Bir mahalleyi anlattyor. Mahalle içindeki yapıyı anlatıyor. Onlar aslında ayrı bir ülke gibi mahallede. Bir de ağır abi takllyyorlar. Böyle silahlar uyuşturucu satmalar, adam vurmalar. Aslında bunlar yanlış, ben de izliyorum ama yanlış şeyler. Çocuklar çok etkileniyor, onlar gibi davranmaya çalışıyorlar. Ağır abi gibi takılmaya çalışıyorlar, grupça takllyyorlar, kavga ediyorlar, mevzu muhabbet falan. Bunlar yanlışşeyler. Daha çok mesela şu anda yapılan Mucize Doktor var. Çok güzel bir dizi. Otizmli olan 
bir doktoru anlatıyor. Otizmli bir insanın toplumda nasıl yer alabileceğini, onların da bu toplumun bir parçası olduğunu anlatıyor. Bu gibi diziler kullanılabilir. İçeriğine dikkat etmek lazım seçerken (K4).

Öğretmen adaylarına göre dizi ve filmler aracılığıyla değerlerin kazandırılması sürecinde kullanılacak dizi ve filmlerin "değerleri doğru şekilde aktarması" da oldukça önemlidir. Bu konudaki katılımcı görüşleri aşağıda verilmiştir:

Değerleri aktarırken mesela bunların anlamını değiştirmemek lazım. Yani mesela töre aslında İslam hukukuyken, şu an herhangi birine sorarsanız töreyi; kardeşini öldürmek, işte kaçarsa öldürmek yani tamamen ölüm akla geliyor. Bunda film ve diziler etkili oldu. Anlamın değiştirdi değerlerimizin. Çoğunu yanlış şekilde aslında aktardı. Bunlara dikkat edilerek diziler filmler yapılırsa insanlar da aslında gerçek doğruları ögrenme firsatı bulurlar (K3).

Bu süreçte her film ve dizi de kullanılamaz. Bilgi ya da değerlerin daha iyi aktardiğ film ve diziler var. Bunlara yönelebilir yöneltebiliriz (K7).

Araştırmaya katılan öğretmen adaylarının bir kısmı değerlerin kazandırılması sürecinde kullanılacak dizi ve filmlerin "gerçek hayatla bağlantılı olması gerektiğini”, bu şekilde değer kazandırma sürecinin daha faydalı olacağını belirtmişlerdir. Bu konudaki katılımcı görüşleri aşağıda verilmiştir:

Orada kullanılan karakterlerin gerçek hayatın çok dışında yaşamamasına dikkat edebiliriz. Yani içimizden birisi olmasına dikkat edebiliriz. Bu insanda kendinden bir şeyler bulmasına sebep olacaktır. Yani daha iyi içine işler, daha etkili olur (K3).

Bir de onların yaşantılarılla doğrudan bağlantılar kurabilecekleri örnek olaylar olmalıdır (K8).

Öğretmen adaylarından K3; "dizi ve filmleri seçerken her dizi ve filmi değil de ögretici olanları seçebiliriz” ifadesiyle bu süreçte kullanılacak olan dizi ve filmlerin öğretici olması gerektiğine işaret etmiştir.

K8 ise ilgi çekici olan dizi ve filmlerin seçilmesi gerektiğine vurgu yapmıştır.

En başta değerlerin kazandırllacă̆ı öğrencilerin öncelikle ilgilerini çekecek film ve diziler seçilmelidir (K8).

Bazı öğretmen adayları dizi ve filmler aracılığıyla değerlerin kazandırılması sürecine yönelik görüş bildirmişlerdir. Bu alt temaya yönelik ortaya çıkan ilk kategori değerlerin bu süreçte "dolaylı olarak aktarılması" gerektiği kategorisidir. 
İlk başlarda direk doğruyu anlatacağız diye değil de birazcık daha davranışı geliştirmek için yapılan çalışmalar olabilir. Mesela tarih filmi anlatılacak, tarih dizisi çekilecek direk şu doğru diye değil şu davranışları yapması güzel olabilir şeklinde sunulabilir. Yani doğrudan değeri değil ama değere götüren değeri öğreten süreci anlatmak gerekir (K6).

Öğretmen adaylarından K7, sürece yönelik görüşler alt temasında "aşamalılık ilkesinin dikkate alınması" gerektiği kategorisinde düşüncelerini ifade etmiştir.

Genelde herkesin bildiği şeylerden başlanabilir. Mesela bunu biliyorum diyerek bir sonraki aşamayı merak edebilirler (K7).

\section{Türk Dizi ve Filmlerinin Değerler Üzerindeki Yansımasına Yönelik Sosyal Bilgiler Öğretmen Adaylarının Görüşleri}

Araştırma bulgularında buraya kadar dizi ve filmlerin değerler eğitimi sürecindeki etkinliğine, bu etkinliğin nedenlerine ve seçim noktasında dikkat edilmesi gereken ölçütlere değinilmiştir. Bu başlık altında ise mevcut Türk dizi ve filmlerinin değerler üzerinde nasıl bir etkiye sahip olduğuna yönelik katılımcı görüşleri aktarılmaya çalışılacaktır. Araştırmaya katılan öğretmen adaylarının tamamı günümüzde yayınlanan Türk dizi ve filmlerinin değerlerimize "olumsuz" olarak yansıdığını düşünmektedirler. Öğretmen adayları tarafından dizi ve filmlere getirilen eleştirilerin başında dizi ve filmlerin değerlerimizi yansıtmamaları hatta değerlerimizi yozlaştırmaya sebep olmaları gelmektedir.

Çok büyük bir kismı bence olumsuz bir etkiye sahip. Çünkü kesinlikle bizim değer ve manevi duygularımızı örf ve adetlerimizi yansitmıyor. Daha çok batı dünyasina göre şekilleniyor (K1).

Türk dizileri alışılmışın dışında olmak için asında bizim geleneklerimiz yansıtmayan diziler. İlgi çeksin diye çoğu zaman şaklabanlık yapabilen diziler. Öldürme patlatma, kadına şiddet gibi. Sadece izlensin ve para kazanilsin amaciyla yapılan diziler (K3).

Değerlerimiz üzerinde olumsuz bir etkiye sahip. Çünkü dizilerde kadın döven erkekler daha sonra o kadını sevince kahraman gibi gösteriliyor. Gitgide saçmalyyorlar. Işste artık kadın cinayetlerinin daha çok olduğu, aldatmanın güzel bir şey gibi gösterildiği diziler var. Sonra bizim ailemizde niye böyle bozukluklar çıklyor diye günümüzü eleştirmek çok saçma geliyor. Bizim dizilerden devaml etkileniyoruz (K4). 
Öncelikle şu anki durumda çok kötü etkilediğini düşünüyorum. Hele birkaç dizi var ahlaki değerleri gerçekten hiçe sayan nitelikte. Aile değerlerini de. Şu anda hala yayında olan bazı diziler var. Zalim İstanbul mesela arada fragmanları önüme geliyor ve fragmant izledikçe diyorum ki bunu izleyen nasıl insanlar olabilir acaba! (K6).

Bence çok kötü bir etkiye sahip. Aşırı derecede olumsuz içerik var. Hatta komple olumsuz içerikten oluşuyor. Ve bence bu olumsuz etkileri ileriki dönemlerde çok daha iyi anlaşılacak da şu anda olumsuz değer kazandırma konusunda acayip etkililer (K8).

Öğretmen adaylarının büyük bir çoğunluğu (K1, K2, K3, K5, K6, K7) değerlere yönelik olumlu içeriğe sahip dizi ve filmlerin de bulunduğunu ancak bunların çok az sayıda olduğunu belirtmişlerdir.

Tamam, ögretici olanlar da var ama bunlar çok az ve zaten izleyici kitlesi de çok sınırlı (K3).

Yani şu anda izlediğim dizilerin pek de öyle ahlaki değerler açısından çok da kötü olduğunu düşünmüyorum. Ama genel olarak değerlendirildiğinde değerler üzerinde olumsuz etkiye sahip (K6).

Mucize doktor dizisi beni çok etkiledi mesela. Otizmli bir çocuğun doktorluğa kadar ilerleyebildiğini, insanların onu nasıl dışladı̆̆ını görüyoruz. Günümüzde de bunun örneklerini görebiliyoruz, karşımıza çıkabiliyor. Fakat bunun ne kadar yanlış olduğunu onlara kucak açmamız gerektiğini öğretiyor. Bu şekilde diziler yararlı da olabiliyor. Ancak bunun gibi yararlı dizileri çok az görüyoruz. Geneli yararsız değerleri olumsuz etkileyen diziler oluşturuyor (K7).

Öğretmen adaylarından bazıları (K1 ve K5) dizi ve filmlerin batı taklitçisi olmasından ve batı kültüründen etkilenmesinden duydukları rahatsızlığı dile getirmişlerdir.

Daha çok batı dünyasına göre şekilleniyor. Onun için mesela çok nadir olsa da değerlerimizi yansitan diziler var ama daha çok batı özentisi olarak görüyorum ben (K1).

Dizilerde aile yapısı olarak daha çok Türk kültüründen çıkmış Batılaşmış. Batıdaki o kültürün etkisiyle oradaki aile yapısından etkilenerek film ve diziler tasarlantyor (K5).

Görüldüğü gibi katılımcılar genel anlamda Türk dizi ve filmlerinin değerler üzerindeki yansımasını olumsuz olarak değerlendirmektedir. Bu noktada dizi 
ve filmlerin değerleri yansıtmaması, değerler üzerinde yıpratıcı bir etkiye sahip olması ve başka kültürleri taklit etmesi gibi eleştiriler öne çıkmıştır.

\section{Sonuç ve Tartışma}

Araştırma sonuçlarına göre araştırmaya katılan sosyal bilgiler öğretmen adaylarının tamamı değerlerin kazandırılması sürecinde dizi ve filmlerin kullanılabileceğini düşünmektedirler. Kurtdede Fidan (2016), tarafından hazırlanan çalışmada araştırmaya katılan 131 öğretmen adayından 99'u değerler eğitiminde yararlanacakları araç-gereç ve kaynaklar arasında film, belgesel, video vb. teknolojileri göstermişlerdir. Bu çalışmada sosyal bilgiler öğretmen adayları günümüzde teknolojinin oldukça geliştiğini, teknolojik aletlerin yaygınlaştığını buna karşın kitap okuma oranının azaldığını vurgulamışlar ve dizi ve filmlerin özellikle görselliğe sahip olmaları ve ilgi çekici olmalarından dolayı bu süreçte kullanılabileceğini belirtmişlerdir.

Öğretmen adaylarının görüşleri doğrultusunda değerlerin kazandırılması sürecinde dizi ve filmleri etkili kılan özellikler şu şekilde sıralanabilir: Dizi ve filmlerin; görselliğe sahip olması ve bu özelliği sayesinde aktarılanların akılda daha kalıcı olması, ilgi çekici olması, birden çok duyu organına hitap etmesi, insanların tembel olmasindan dolayı dizi ve filmleri tercih etmesi, insanları etkileme gücüne sahip olması, yaygın olması ve olayları somutlaştırması. Kaya ve Çengelci (2011, s. 129) tarafından öğretmen adaylarının sosyal bilgiler eğitiminde filmlerden yararlanılmasına ilişkin görüşlerini belirlemek amacıyla hazırlanan çalışmada araştırmaya katılan öğretmen adayları filmlerin öğrenme-öğretme sürecinde birden çok duyu organına hitap eden, kalıcı ve eğlenceli bir öğrenmeye destek sağladığının altını çizmişler ve filmlerin öğrenilenleri somutlaştırdığını ifade etmişlerdir. Ayrıca çalışmada katılımcılar sosyal bilgiler eğitiminde film kullanımının değerlerin kazandırılmasına katkı sağladığını da belirtmişlerdir. Ulaşılan bu bulgular, çalışmamızda ulaşılan bulgularla benzerlik göstermektedir. Varghese ve Raman (2014, s. 339) Hindistan'da eğitim ortaminda filmlerin kullanılması temeline dayanan Okul Sinemas1 (School Cinema) projesi kapsamında filmlerin değerler eğitiminde kullanılmasının etkilerini araştırmışlardır. Çalışmada filmlerin değerler eğitiminde kullanılabilecek etkin bir araç olduğu ifade edilmiştir. Russell III ve Waters (2010), çalışmaları sonucunda sınıfta film kullanımının öğrencilerin karar verme süreçlerine ve etkin vatandaş olma amacıyla değerlerini analiz etmelerine yardımcı olacağını savunmuşlardır. Araştırmacılar aynı çalışmada etkin vatandaşlık eğitimi için sınıf 
ortamında kullanılabilecek film önerilerinde de bulunmuşlardır. Kurtdede Fidan (2009), öğretmen adaylarının değer öğretimine ilişkin görüşlerini belirlemek amacıyla hazırladığı çalışmada araştırmaya katılan öğretmen adaylarından büyük çoğunluğunun "değer öğretiminde değer boyutu olan sinema filmi, TV filmi ve tiyatro önerilmelidir" görüşüne sahip olduğunu ifade etmiştir. Benzer görüşler bu araştırmanın katılımcıları tarafindan da ifade edilmiştir. Sturma (1997) ise çalışmasında tarihî filmlerin değerler ve davranışlar üzerinde etkili olduğunu vurgulamıştır.

Öğretmen adaylarına göre dizi ve filmler aracılığıyla değerler kazandırılırken dikkat edilmesi gereken önemli noktalar bulunmaktadır. Bu konudaki görüşler içeriğe yönelik görüşler ve sürece yönelik görüşler temaları altında toplanmıştır. İçeriğe yönelik görüşler şu şekildedir: Bu süreçte kullanılacak dizi ve filmlerin içeriğinin uygun olması, değerlerin doğru şekilde aktarılıyor olması, dizi ve filmlerin gerçek hayatla bağlantılı olması, öğretici olması ve ilgi çekici olması. Sürece yönelik görüşler ise değerlerin dolaylı olarak anlatılması gerektiği ve aşamalılık ilkesinin dikkate alınması gerektiği maddelerinden oluşmaktadır. Öztaş (2017) da tarihi filmlerin değerler eğitiminde kullanılabileceğini ifade etmekle birlikte özellikle içerik bakımından uygun olmayan filmlerin bu süreçte kullanılmaması gerektiğini belirtmiştir. Kurtdede Fidan'ın (2009, s. 16), belirtilen çalışmasında, çalışmaya katılan öğretmen adayları da içerik bakımında uygun olan dizi ve filmlerin değerlerin kazandırılması sürecinde kullanılabileceğini belirtmişlerdir.

Araştırmada Türk dizi ve filmlerinin değerler üzerindeki yansımasına yönelik sosyal bilgiler öğretmen adaylarının görüşleri de belirlenmeye çalışılmıştır. Elde edilen sonuçlara göre araştırmaya katılan sosyal bilgiler öğretmen adaylarının tamamı Türk dizi ve filmlerinin değerler üzerinde olumsuz etkiye sahip olduğunu düşünmektedirler. Şahin (2010, s. 134) tarafindan öğretmenlerin zorbalık algılarını belirlemek amacıyla hazırlanan çalışmada öğretmenlere göre görsel medya ve özellikle de televizyon dizilerinin zorbalığın en önemli nedenlerinden birisi olduğu bulgulanmıştır. Çalışmada o dönemde Türkiye'nin en çok izlenen dizilerinden olan Kurtlar Vadisi örnek olarak sunulmuş ve dizide sıkça kullanılan şiddet unsurlarının lise öğrencileri üzerinde olumsuz bir etkiye sahip olduğu vurgulanmıştır. Berkant, Efendioğlu ve Sürmeli (2014, s. 434), sosyal bilgiler ve sınıf öğretmenlerinin değerler eğitimine yönelik görüşlerini incelemek amacıyla hazırladıkları çalışmada öğretmenler tarafından TV dizilerinin değerler üzerindeki olumsuz etkisi, öğrencilerin değer kazanımında güç- 
lük yaşama nedenleri arasında gösterilmiştir. Dolayısıyla belirtilen çalışmaların sonuçları bu çalışmada elde edilen sonuçlarla benzerlik göstermektedir.

Öğretmen adayları değerler üzerinde olumlu etki edebilecek ve bu süreçte kullanılabilecek Türk dizi ve filmlerinin de bulunduğunu ancak bunların çok az sayıda olduğunu, dizi ve filmlerin büyük bir çoğunluğunun olumsuz içeriklerinden dolayı bu süreçte kullanılmaması gerektiğini belirtmişlerdir. Ocak ve Selimoğlu (2016, s. 431), "Tarih öğretiminde tarih dizilerinin kullanımına ilişkin öğrenci görüşlerini belirlemek" amacıyla hazırladıkları çalışmada 14 öğrenciden 11'i dizilerin öğrencileri olumsuz yönde etkilediğini, sekiz öğrenci ise dizilerin bu şekliyle öğretim materyali olarak kullanılamayacağını belirtmiştir. Sonuç olarak tarih dizilerinin tarih öğretiminde oldukça önemli olduğuna fakat dizilerin sahip olduğu olumsuz içeriklerinden dolayı tarih derslerinde kullanımının mümkün olamayacağı sonucuna varılmıştır. Demir ve Gezici (2018, s. 407), "tarihi dizi ve filmlerin sosyal bilgiler dersine yansımaları" başlıklı çalışmalarında 10 sosyal bilgiler öğretmeni ile görüşmüşlerdir. Çalışmada tarihi dizi ve filmlerin derste öğrenilen bilgilerin öğrencilerin zihinlerinde somutlaşmasına katkı sağladığı bununla birlikte bazı dizi ve filmlerde yer alan müstehcen veya şiddet içerikli sahnelerin öğrencilere kötü örnek teşkil ettiği araştırmaya katılan öğretmenler tarafından dile getirilmiştir. Belirtilen çalışmalar (Ocak ve Selimoğlu, 2016; Gezici ve Demir, 2018) tarihi dizi ve filmler bağlamında konuyu ele almışlardır. $\mathrm{Bu}$ çalışmada ise dizi ve filmler genel olarak değerlendirilmiştir. Bununla birlikte tarihi dizi ve filmlere yönelik görüşlerin benzerlerine genel anlamda dizi ve filmlere odaklanan bu çalışmada da ulaşılmıştır. Bu araştırma sonucunda da öğretmen adayları dizi ve filmlerin değerlerin kazandırılması sürecinde kullanılabileceğini ancak gönümüzde yayınlanan birçok dizi ve filmin değerlerin kazandırılması sürecinde kullanılmaması gerektiğini belirtmişlerdir.

Öğretmen adayları tarafından Türk dizi ve filmlerine getirilen en önemli eleştiri Türk dizi ve filmlerinin değerleri yansıtmaması noktasında olmuştur. Ayrıca araştırmaya katılan birçok öğretmen adayı Türk dizi ve filmlerinin değerleri yansıtmadığı gibi değerler üzerinde yıkıcı ve yıpratıcı bir etkiye sahip olduğunu da düşünmektedir. Zavalsız ve Soydaş Dağcı (2019), tarafından hazırlanan çalışmada izleyicilerin takip ettikleri bir diziyi izlemeyi bırakma nedenlerinin başında dizilerin ahlaki değerlere uygun olmaması gösterilmiştir. Bazı katılımcılar da Türk dizi ve filmlerini batı taklitçiliği yapmalarından dolayı eleştirmiş, bu dizi ve filmlerin batı kültürünü ve değerlerini aktardığını ifade etmişlerdir.

Görüldüğü gibi araştırmanın katılımcıları genel olarak Türk dizi ve filmlerinin değerler üzerinde olumsuz etkiye sahip olduğunu düşünmektedir. Ancak 
burada üzerinde durulması gereken önemli bir nokta bulunmaktadır. Dizi ve filmlerde yer alan olumsuz davranışların kötü karakterler tarafından sergilenmesi ya da dizi ve film kahramanlarının sergiledikleri olumsuz davranışlardan devam eden sahnelerde pişmanlık duyması ve doğruya yönelmesi gibi durumlar izleyicilerin bu sahnelerden olumlu yönde etkilenmelerine katk1 sunabilir. Benzer şekilde bir değerin kazandırılabilmesi amacıyla zaman zaman olumsuz durumlar örnek olarak kullanılabilir ve bu şekilde izleyicinin ahlaki muhakeme yapması sağlanarak izleyici doğruya yönlendirilebilir.

Elde dilen bulgular 1şığında genel bir değerlendirme yapmak gerekirse; araştırmaya katılan sosyal bilgiler öğretmen adaylarının tamamı diziler ve filmler aracılığıyla değerlerin kazandırılabileceğini düşünmektedir. Ancak yine aynı öğretmen adaylarının tamamı günümüzde televizyon ekranları ve sinema perdeleri aracılığıyla izleyicilerle buluşan Türk dizi ve filmlerinin büyük çoğunluğunun çeşitli sebeplerle değerlerin kazandırılması sürecinde kullanılamayacağını düşünmektedir.

\section{Öneriler}

$\mathrm{Bu}$ çalışma ve alanyazında yapılan benzer çalışmaların sonuçları dikkate alındığında dizi ve filmlerin değerlerin kazandırılması sürecinde kullanılabileceği anlaşılmaktadır. Ancak yine çalışmalar göstermiştir ki bu süreçte kullanılacak dizilerin ve filmlerin seçiminde çok dikkatli olmak gerekmektedir. Özellikle günümüzde değerler üzerinde olumsuz etki gösterebilecek, değerleri olumsuz etkileyebilecek çok sayıda dizi ve film bulunmaktadır. Dolaysıyla değerler eğitiminde dizi ve filmlerden yararlanırken kullanılacak dizi ve filmlerin uygun içeriğe sahip olduğundan emin olunmalıdır.

Özellikle ailelerin çocuklarının izledikleri dizi ve filmlerin içeriklerinden haberdar olmaları gerekmektedir. Bu, çocukların olumsuz unsurlar barındıran dizi ve filmlere maruz kalmalarını engelleme açısından önem taşımaktadır. Ailelerin çocuklarını bu konuda bilinçlendirmesi ve kendilerinin de onlara örnek olması fayda sağlayacaktır.

Araştırmada Türk dizi ve filmlerinin değerler üzerindeki yansıması ele alınmış ve katılımcıların tümü Türk dizi ve filmlerinin değerler üzerinde olumsuz yansımaya sahip olduğunu ifade etmişlerdir. Çalışmada yabancı dizi ve filmlerin değerler üzerindeki yansıması ise ele alınmamıştır. Özellikle gençler arasında giderek yaygın hale gelen yabancı dizi ve film hayranlığı göz önüne alındı- 
ğında yabancı dizi ve filmlerin değerler üzerindeki yansımasının incelenmesi faydalı olacaktır.

Değerlerine sahip çıkan, sağlam karakterli bireylere duyulan ihtiyacın her geçen gün daha fazla hissedildiği bununla birlikte gerek diziler gerekse filmler arac1lı̆̆ıyla olumsuz örneklerin her gün izleyicilerle buluştuğu günümüz dünyasında değerler eğitimi sürecinde kullanılabilecek dizi ve filmlerin hazırlanması oldukça önemlidir. Bu konuda ilgili kurumların sorumluluk alması gerekmektedir.

\section{Kaynakça}

Akıncı Yüksel, N. A. (2015). Kültürel bir ürün olarak Türkiye'de sinema filmlerinde okul, öğretmen ve öğrenci temsilleri. Global Media Journal: Turkish Edition, 6(11), 1-17. https://globalmediajournaltr.yeditepe.edu.tr/guz-2015sayisi-fall-2015-issue

Ağırseven, N., ve Örki, A. (2017). Evaluating Turkish tv series as soft power instruments. OPUS - International Journal of Society Researches, 7(13), 836-853. https://doi.org/10.26466/opus.353287

Aydın, M. Z., ve Gürler, Ş. A. (2014). Okulda değerler eğitimi. Nobel Yayınları.

Banks, J. A., \& Banks C. M. (2007). Multicultural education, issues and perspectives. (6th Editon). Hoboken, NJ: John Wiley.

Berkant, H. G., Efendioğlu, A., ve Sürmeli, Z. (2014). Değerler eğitimine yönelik öğretmen görüşlerinin incelenmesi. Electronic Turkish Studies, 9(5), 427440. https://doi.org/10.7827/TurkishStudies.6732

Biesta, G. J. J. (2010). Why 'what works' still won't work: From evidence-based education to value-based education. Studies in Philosophy and Education, 29(5), 491-503. https://doi.org/10.1007/s11217-010-9191-x

Blaylock, L. (2003). Religious education and citizenship: some reflections, R. Jackson (Ed.) International perspectives on citizenship, education and religious diversity içinde (209-221), Routledge Falmer.

Braun, V., \& Clarke, V. (2019). Psikolojide tematik analizin kullanımı. S. N. Şad, N. Özer ve A. Atli (Çevirenler). Eğitimde Nitel Araştırmalar Dergisi Journal of Qualitative Research in Education, 7(2), 873-898. https://doi. org/10.14689/issn.2148-2624.1.7c.2s.17m

Box Office Türkiye (2019). Erişim adresi: https://boxofficeturkiye.com/ Son erişim tarihi: 10.01 .2020 
Coates, H. (2005). The value of student engagement for higher education quality assurance. Quality in Higher Education, 11(1), 25-36. https://doi. org/10.1080/13538320500074915

Çalık, M., ve Sözbilir, M. (2014). İçerik analizinin parametreleri. Eğitim ve Bilim, 39(174), 33-38. https://doi.org/10.15390/EB.2014.3412

Dal Cin, S., Worth, K. A., Gerrard, M., Stoolmiller, M., Sargent, J. D., Wills, T. A., \& Gibbons, F. X. (2009). Watching and drinking: expectancies, prototypes, and friends' alcohol use mediate the effect of exposure to alcohol use in movies on adolescent drinking. Health Psychology: Official journal of the Division of Health Psychology, American Psychological Association, 28(4), 473-483. https://doi.org/10.1037/a0014777

Dalton, M. A., Sargent, J. D., Beach, M. L., Titus-Ernstoff, L., Gibson, J. J., Ahrens, M. B., ... Heatherton, T. F. (2003). Effect of viewing smoking in movies on adolescent smoking initiation: a cohort study. The Lancet, 362(9380), 281285. https://doi.org/10.1016/S0140-6736(03)13970-0

Demir, F. (2018). Değer öğretimi yaklaşımlarına göre hayat bilgisi dersinde değerler eğitimi [Yayımlanmamış doktora tezi], İnönü Üniversitesi Eğitim Bilimleri Enstitüsü.

Demir, S. B. ve Gezici, M. (2018). Tarihi dizi ve filmlerin sosyal bilgiler dersine yansımalar1. Turkish History Education Journal, 7(2), 392-413. https://doi. org/10.17497/tuhed.446031

Demirkaya, H., ve Çal, Ü. T. (2018). Sosyal bilgiler öğretmen adaylarının dürüstlük değerine ilişkin metaforik algıları. Kırşehir Eğitim Fakültesi Dergisi, 19(3), 1964-1980. https://doi.org/.29299/kefad.2018.19.03.005

Doğanay, A. (2009). Değerler Eğitimi. Öztürk. C. (Ed.) Sosyal Bilgiler Öğretimi Demokratik Vatandaşlık Eğitimi Değerler Eğitimi (s. 226-254) içinde, Pegem Akademi.

Erjem, Y. ve Çağlayandereli, M. (2006). Televizyon ve gençlik: yerli dizilerin gençlerin model alma davranışı üzerindeki etkisi. C. Ü. Sosyal Bilimler Dergisi, 30(1), 15-30. https://app.trdizin.gov.tr/makale/T0Rrek1UTXo

Gibson, W. J.\& Brown, A. (2009). Working with Qualitative Data, SAGE Publications.

Gündüz, M. (2016). Classifying Values by categories. Journal of Education and Training Studies, 4(10), 212-220. https://doi.org/10.11114/jets.v4i10.1765

Karakuş, N. (2015). Okul öncesi döneme hitap eden tema içerikli çizgi filmlerin değerler eğitimine katkısı yönünden değerlendirilmesi (Niloya Örneği). Değerler Eğitimi Dergisi, 13(30), 251-277. https://dergipark.org.tr/tr/pub/ded/ issue/29166/312334 
Kaya, E., ve Çengelci, T. (2011). Öğretmen adaylarının sosyal bilgiler eğitiminde filmlerden yararlanılmasına ilişkin görüşleri. Journal of Social Studies Education Research, 2(1), 116-135. https://jsser.org/index.php/jsser/article/view/126

Kaymakcan, R., ve Meydan, H. (2010). Demokratik vatandaşlık ve din öğretimi: yeni yaklaşımlar ve Türkiye'de DKAB dersleri bağlamında bir değerlendirme. İn̈̈nӥ Üniversitesi Illahiyat Fakültesi Dergisi, 1(1), 29-53.

Kaymakcan, R., ve Meydan, H. (2020). Ahlak, değerler ve eğitimi (3. Baskı). Dem Yayınları.

Keleş, E. ve Çepni, S. (2006). Beyin ve öğrenme. Journal of Turkish Science Education, 3(2), 66-82. https://www.tused.org/index.php/tused/article/view/494

Keskin, Y. (2008). Türkiye'de sosyal bilgiler öğretim programlarında değerler ĕgitimi: Tarihsel gelişsim, 1998 ve 2004 programlarının etkililiğinin araştırtlması. [Yayımlanmamış doktora tezi], Marmara Üniversitesi Eğitim Bilimleri Enstitüsü.

Kim, S.S., Agrusa, J., Lee, H., and Chon, K. (2007). Effects of Korean television dramas on the flow of Japanese tourists. Tourism Management, 28, 13401353. https://doi.org/10.1016/j.tourman.2007.01.005

Kurtdede Fidan, N. (2009). Öğretmen adaylarının değer öğretimine ilişkin görüşleri. Kuramsal Eğitimbilim Dergisi, 2(20), 1-18. https://dergipark.org.tr/tr/ pub/akukeg/issue/29339/313960

Kurtdede Fidan, N. (2016). Sınıf öğretmeni adaylarının geleceğe yönelik değerler eğitimi tasarıları. International Journal Of Eurasia Social Sciences, 7(22), 161180. http://www.ijoess.com/DergiTamDetay.aspx?ID=430\&Detay=Ozet

MEB. (2018). Sosyal bilgiler dersi ögretim programı. http://mufredat.meb.gov. tr/Dosyalar/201812103847686-SOSYAL\%20B\%C4\%BOLG\%C4\%BOLER\%20\%C3\%96\%C4\%9ERET\%C4\%BOM\%20PROGRAMI\%20.pdf

Merriam, S. B., \& Tisdell, E. J. (2015). Qualitative Research. A Guide to Design and Implementation (4. Bask1). Jossey-Bass.

Miller, T. (2015). Stuttering in the Movies: Effects on Adolescents' Perceptions of People who Stutter. WWU Graduate School Collection. 409.

Ocak. G., ve Selimoğlu, S. (2016). Tarih öğretiminde tarih dizilerinin kullanımına ilişkin öğrenci görüşleri-nitel bir analiz. Kastamonu Üniversitesi Kastamonu Ë̆itim Dergisi, 24(1), 431-452. https://dergipark.org.tr/tr/pub/kefdergi/ issue $/ 22606 / 241623$

Özdemir Adak, A., ve Ramazan, O. (2012). Çizgi filmlerin çocukların davranışları üzerindeki etkisinin anne görüşlerine göre incelenmesi. Marmara Üniversi- 
tesi Atatürk Eğitim Fakültesi Eğitim Bilimleri Dergisi, (35), 157-173. https:// dergipark.org.tr/tr/pub/maruaebd/issue/375/2219

Öztaş, S. (2017). Ortaöğretim tarih derslerinde tarihi filmlerin değer eğitiminde kullanımı. Insan ve Toplum Bilimleri Araştırmaları Dergisi, 6 (5), 3076-3099. http://www.itobiad.com/tr/pub/issue/31500/357560

Öztaş, S. Anıl, N. K., ve Kılıç, B. (2013). Tarihi film veya tarihi dizilerin tarihe ilgiyi artırmada etkisine ilişkin MYO öğrencilerinin görüşleri. Electronic Journal of Vocational Collages, 3(4), s. 107-120. https://doi.org/10.1501/ OTAM_0000000417

Özturhan, F. (2019). Imam Hatip Lisesi Öğrencilerinin Güney Kore Dizileri İzleme Durumları ve Dizilerin Etkileri, [Yayımlanmamış Yüksek Lisans Tezi], Necmettin Erbakan Üniversitesi Sosyal Bilimler Enstitüsü.

Öztürk, B. (1999). Öğrenme ve öğretmede dikkat. Milli Eğitim Dergisi, 144, 51-58. https://dhgm.meb.gov.tr/yayimlar/dergiler/Milli_Egitim_Dergisi/144/ozturk.htm

Paker, T. (2017). Durum Çalışması. Seggie, F. N. ve Bayyurt, Y. (Ed.) Nitel Araştırma Yöntem, Teknik, Analiz ve Yaklaşımları (2. Baskı) (s. 119-134) içinde. Anı Yayıncılık.

Parke, R. D., Berkowitz, L., Leyens, J. P., West, S. G., \& Sebastian, R. J. (1977). Some effects of violent and nonviolent movies on the behavior of juvenile delinquents. Advances in Experimental social Psychology, 10, 135-172. https://doi.org/10.1016/S0065-2601(08)60356-1

Radyo ve Televizyon Üst Kurulu (RTÜK) (2018). Televizyon izleme eğilimleri araştırmast-2018. https://www.rtuk.gov.tr/assets/Icerik/AltSiteler/televizyonizlemeegilimleriarastirmasi2018.pdf

Radyo ve Televizyon Üst Kurulu (RTÜK) (2020). Çocukların medya kullanım alışkanlıkları ve siber zorbalık araştırması. https://www.rtuk.gov.tr/haberler/3787/8175/dikkat-ceken-arastirmanin-sonuclari-aciklandi.html

Russell III, W. B., \& Waters, S. (2010). Cinematic citizenship: Developing citizens of character with film. Action in Teacher Education, 32(2), 12-23. https:// doi.org/10.1080/01626620.2010.10463547

Russell III, W. B., \& Waters, S. (2013). "Reel" character education: Using film to promote global citizenship. Childhood Education, 89(5), 303-309. https:// doi.org/10.1080/00094056.2013.830901

Semerci, N., ve Kalçık, C. (2017). Televizyonda yayınlanan dizilerin lise öğrencilerinin yaşam boyu öğrenmesine etkisi öğrenci görüşleri: Bir olgu bilim çalışması (Bartın ili örneği). Bartın Üniversitesi Eğitim Fakültesi Dergisi, 6(1), 237-262. https://doi.org/10.14686/buefad.280034 
Smithikrai, C. (2016). Effectiveness of teaching with movies to promote positive characteristics and behaviors. Procedia-Social and Behavioral Sciences, 217, 522-530. doi: 10.1016/j.sbspro.2016.02.033

Sözer, E. (1998). Sosyal Bilgiler Programının Amaçları, İlkeleri ve Temel Özellikleri. Can, G. (Ed.) Sosyal Bilgiler Öğretimi (s. 15- 39) içinde. Anadolu Üniversitesi Yayınları.

Strauss, A. \& Corbin, J. (1997). Grounded Theory in Practice. Thousand Oaks, Sage.

Sturma, M. (1997). Feature film and teaching/learning. R. Posbisil \& L. Willcoxson (Eds.) Learning Through Teaching (pp. 312-313). Teaching and Learning Forum. Murdoch University, Perth.

Şahin, M. (2010). Teachers' perceptions of bullying in high schools: A Turkish study. Social Behavior and Personality: an International Journal, 38(1), 127-142. https://doi.org/10.2224/sbp.2010.38.1.127

Şahin, T., ve Ersoy, F. (2012). Sosyal bilgiler ders kitaplarının değerler eğitimi yaklaşımları açısından incelenmesi. Kuram ve Uygulamada Eğitim Bilimleri Dergisi, 12(2), 1535-1558. https://www.idealonline.com.tr/IdealOnline/lookAtPublications/paperDetail.xhtml?uId=1851

Ulusoy, K., ve Dilmaç, B. (2012). Değerler eğitimi. Pegem Akademi.

Ulusoy, K. (2019). Karakter Değerler ve Ahlak Ĕ̆itimi. Pegem Akademi.

Ünal, O. (2020a). Eğitim temalı Türk filmlerinde yer alan değerlerin incelenmesi. Değerler Ĕ̈itimi Dergisi, 18 (39), s.107-136. https://doi.org/10.34234/ded.608530

Ünal, O. (2020b). Türk filmlerinde yer alan değerlerin incelenmesi. Anadolu Journal of Educational Sciences International, 10(2), 910-929. https://doi. org/10.18039/ajesi.759910

Xu, M. (2018). American TV Series in China: How Online Viewing Impacts Perceptions of Reality, Cultural Values and Identity. [Unpublished $\mathrm{PhD}$ Thesis], University of Canterbury, College of Arts. Christchurch.

Varghese, A. M. \& Raman, U. (2014). Value education in schools: School cinema versus the moral science textbook. International Journal of Education and Management Studies, 4(4), 339-342. https://www.myresearchjournals.com/ index.php/IJEM/article/view/706

Yakar, H. G. İ. (2013). Sinema filmlerinin eğitim amaçlı kullanımı: Tarihsel bir değerlendirme. Hasan Ali Yücel Eğitim Fakültesi Dergisi, 19(1), 21-36. https://hayefjournal.org/en/sinema-filmlerinin-egitim-amacli-kullanimi-tarihsel-bir-degerlendirme-13496

Yeşil, R., ve Aydın, D. (2007). Demokratik değerlerin eğitiminde yöntem ve zamanlama. Türkiye Sosyal Araştırmalar Dergisi, 11(2), 65-84. 
Yıldırım, A., ve Şimşek, H. (2018). Sosyal Bilimlerde Nitel Araştırma Yöntemleri (11. Bask1). Seçkin Yayıncılık.

Zavalsız, Y. S., ve Soydaş Dağcı, Y. (2019). Televizyon dizilerinin toplum üzerindeki etkisi (Karabük örneği). Çukurova Üniversitesi İlahiyat Fakültesi Dergisi (ÇÜIFD), 19(1), 185-201. https://doi.org/10.30627/cuilah.549553 
Extended Abstract

\section{Social Studies Teachers Candidates' Opinions about the Impact of Series and Films on Values}

Orhan ÜNAL, Corresponding Author, Research Assistant.

Ondokuz Mayss University, Faculty of Education, Samsun / Turkey.

orhanuna107@hotmail.com

https://orcid.org/0000-0002-4604-6210

Article Type: Research Article

https://doi.org/10.34234/ded.906251

Received Date: 30.03 .2021

Accepted Date: 11.06 .2021

Published Date: 25.06 .2021

\section{Introduction}

Values are behaviors that are defined and accepted as correct and beautiful by the public. People are not born as having values. However, they can acquire these values through their lives, experiences, environment, and education (Yeşil and Aydin, 2007). The livability of the society we live in depends on individuals who preserve their values and strive to transfer values to future generations. All the studies carried out regarding students acquisition of values can be defined as values education. Values education starts in the family and continues in school and the environment (Ulusoy, 2019).

The history of values education in Turkey has very well-established history. Nevertheless, values education has not been directly involved in the curriculum until recently. Especially when the social studies course curricula are taken into consideration, values for the first time directly included in the Social Studies 
Course Curriculum that published in 2004 (Keskin, 2008). Similarly, values directly included in the Social Studies Curriculum published in 2018 (MEB, 2018).

Various methods and materials are used in values education. Especially in today's world where technological developments and the impact of the media sector on people and people's daily habits are highly felt, series and films appear as effective materials in educational processes. People have a great interest in series and movies since they can appeal to multiple senses, and are engaging and easily accessible in different environments. Considering the data regularly published by RTÜK every year, Turkish people spend an average of 3 hours and 34 minutes watching television daily in 2018 (RTÜK, 2018). According to another study prepared by RTÜK, the most frequently watched program type by secondary school students was series with $51.5 \%$, films with $41 \%$, and live sports competitions/sports programs with $28 \%$. The interest of the Turkish people in the movies also has been increasing over the years. In Turkey, 27 million 800 thousand people in 2005 watched the films in movie theaters. In 2018, this number reached 70 million 400 thousand people.

\section{Purpose and Significance}

The studies reveal that the characters of the series and films have an impact on people that they try to identify themselves with the characters and try to act like them (Erjem ve Çağlayandereli, 2006; Kim, Agrusa, Lee ve Chon, 2007; Semerci ve Kalçık, 2017). The fact that the series and movies, which have an important place in our daily life, can reach large audiences quickly and influence the audience with messages they give requires close examination from different perspectives.

When the social studies course content is examined, it is seen that this course has an essential place in the education of values. Therefore, the opinions of teacher candidates who will teach in the field of social studies is of utmost importance. In this context, the study has been prepared in order to reveal the views of teacher candidates of social studies lesson on the use of series and films in instilling values and the impact of Turkish series and films on values. In this context, answers to the following questions were sought:

1. What are the opinions of social studies teacher candidates about the use of TV series and films in values education?

2. According to Social Studies teacher candidates, to what attention should be paid when using TV series and films in value education? 
3. What is the impact of Turkish TV series and movies on values according to social studies teacher candidates?

\section{Methodology}

This study utilized basic qualitative research design in accordance with the qualitative research method. Basic qualitative research can be expressed as studies conducted to reveal the opinions and thoughts of the participants on a topic with qualitative data (Merriam \& Tisdell, 2015). Eight social studies teacher candidates constitute the study group of the research. The criterion sampling method, one of the purposeful sampling methods, was used to select the study group. The criteria used in selecting the working group are as follows: Watching at least one movie in the last three months, regularly following at least one series, and having completed at least two years of four-year undergraduate program. Research data were collected through interview forms prepared by the researcher. Research data were collected by interview method, which is frequently used in qualitative research. Interviewing is a mutual and interactive communication process that is pre-designed, conducted for a specific purpose, and based on asking questions and answering (Stewart \& Cash, 1985; cited in Yıldırım \& Şimşek, 2018, p.129). The interview was conducted face-to-face with the participants, and a voice recorder was used to record the interview. Thematic analysis was used to analyze the data. Thematic analysis is a method for identifying, analyzing, and reporting patterns (themes) within data (Braun and Clarke, 2019).

\section{Results}

All the teacher candidates who participated in the research stated that values could be gained through series and films. They listed the features that made the series and films effective in this process as follows: The visuality of films and TV series makes them engaging, they also appeal to multiple senses, they have the power to affect people, they are common, they embody events and these tools are preferred by people who are prone to be lazy. Participants also stated the points that should be considered while using series and movies in educational process under two sub-themes. The first sub-theme consists of views on the content of the series and films. Categories related to this sub-theme are as follows: Content should be appropriate, should be related to real life, should be 
instructive and interesting and values should be conveyed correctly. The second sub-theme consists of views on the process of transferring values through series and films. Categories of the second theme are as follows: Values should be transferred implicitly, and the principle of phasing should be considered.

All the teacher candidates who participated in the study think that the recent Turkish serials and movies affect the values negatively. The main criticism brought to the series and films by the participants is that the series and films do not reflect the desired values and even cause corruption of values. Most of the participants stated that there were series and films with positive content about the values, but they were very few.

\section{Discussion and Conclusion}

According to study results, all the social studies teacher candidates who participated in the research think that serials and films can be used in the process of values acquisition. In the study conducted by Kaya and Çengelci (2011), the participants stated that films provide support for permanent and entertaining learning that appeals to multiple sensory organs in the learning-teaching process and that the films embody the teaching. Likewise, in the study of Varghese and Raman (2014), it was claimed that films are an effective tool that can be used in values education. In the study of Kurtdede Fidan (2009), candidate teachers participating in the research suggest that cinema movies, TV film, and drama, which contain values that appropriate for students, should be recommended. The candidate teachers who participated in this study stated that suitable series and films could be used in the process of values acquisition.

All the social studies teacher candidates who participated in this study think that Turkish serials and films have negative effects on values. Similar results were obtained from the studies conducted by Şahin (2010), Yazar (2012), Berkant, Efendioğlu, and Sürmeli (2014). However, candidate teachers stated that there are some Turkish serials and films that can have a positive effect on the values and can be used in educational process, but they are very few. Ocak and Selimoğlu (2016), Gezici and Demir (2018) have reached similar results in their studies. However, there is a critical point that should be emphasized here, that in storylines where evil characters or the leading actors display negative behaviors then showing regret and brought back to right path can create positive influence 
on the audience. Similarly, negative situations may be used as an example to emphasize the desirable value. In this way, the audience can be directed towards the truth by providing moral reasoning.

According to the findings of this study, the following suggestions could be made: It is necessary to be careful that the series and films to be used in values acquisition are appropriate in terms of content. Families need to pay attention to the content of the series and films that their children watch. This is important in terms of preventing children from being exposed to series and films that contain harmful elements. It will also be helpful to prepare appropriate series and films that can be used in the process of values education.

Etik Beyan / Ethical Statement: Bu çalışmanın hazırlanma sürecinde bilimsel ve etik ilkelere uyulduğu ve yararlanılan tüm çalışmaların kaynakçada belirtildiği beyan olunur. / It is declared that scientific and ethical principles have been followed while carrying out and writing this study and that all the sources used have been properly cited.

Finansman / Funding: Yazar, bu araştırmayı desteklemek için herhangi bir dış fon almadığını kabul eder. / The author acknowledges that he recevied no external funding in support of this research. 